\title{
Descriptive Research of Social Capital among Low Income Group in Urban Areas in East Coast of Peninsular Malaysia
}

\author{
Aziz Amin, Zainul Zolkifeli, Mohd Syaiful Nizam Abu Hassan
}

\begin{abstract}
The purpose of this study is to identify the descriptive analysis of social capital among low income group. Technological advances make society less directly connected among themselves. According to Malaysia Department of Statistics in 2015, there was 2.7 million of the low income group B40, with 63\% living in the urban areas while $37 \%$ lived rural areas. This is intense circumstance since family pay can influence others perspectives throughout somebody's life, for example, personal satisfaction. Social Capital can turn into an apparatus so as to beat this issue and networks are urged to utilize this instrument admirably. This investigation included 288 respondents among low salary bunch in Kota Bharu, Kuala Terengganu and Kuantan. Information was gathered utilizing surveys and analysis was directed utilizing SPSS programming. The outcome demonstrates the component of social capital has a positive dimension. This finding can be used as a foundation to make a predominant procedures or program by the administration with a particular ultimate objective to diminish the dimension of B40 in Malaysia.
\end{abstract}

Index Terms:- Low-income group, social capital, urban areas.

\section{INTRODUCTION}

In order to build up the country, communities will be one of an important part. A few past studies focus on certain community like research by [1] which was look at the factors affecting community participation towards polio immunization in Nigeria. In [2] also focus on quality of life community that participated in homestay program in Malaysia. It shows that communities are very important assets to the country. Likewise social capital is thought of a part of community as something like a general public from crumbling; it speaks to a person's associations with different people, which fill in as a reason for different social systems to shape. Like human capital, from one viewpoint, social capital is seen as something typified in a person. Dissimilar to human capital, then again, its part has been thought of as more towards making outside economies to a general public [3], [4]. Social capital in like manner can be fundamentally said as the preferred standpoint installed in the social relationship and can be investigated and utilized for some particular goals, in any case, since social capital is on an essential dimension unpretentious, there is still no uniform thankfulness, neither exact definition [5]. In [6] depicted

Revised Manuscript Received on July 10, 2019.

Aziz Amin, Faculty of Applied Social Science (FSSG), Universiti Sultan Zainal Abidin, Gong Badak Campus, 21300 Terengganu, Malaysia.

Zainul Zolkifeli, Faculty of Applied Social Science (FSSG),

Universiti Sultan Zainal Abidin, Gong Badak Campus, 21300 Terengganu, Malaysia.

Mohd Syaiful Nizam Abu Hassan, Faculty of Applied Social Science (FSSG), Universiti Sultan Zainal Abidin, Gong Badak Campus, 21300

Terengganu, Malaysia. social capital as the structure of relationship systems and data accessible to an individual, while in [7] even simply portrayed social capital as a kind of capital, and can be made when the relationship between people is used to engage their activities. The research conducted by [8] shows that social capital and mental health has contributed 57 percent towards quality of life. Moreover in the modernization era, technological advances make society less directly connected among themselves. Therefore, this study is to identify the descriptive analysis of social capital among low income group. The changing and conflicting definitions about social capital outcome in different thankfulness about its estimations, different measurements, grouped structures, even unique qualities can distribute capital into various estimations. From the undeniable measurements viewpoint, social capital can be separated into specific measurement, including central focuses or potential inclinations that gather to a performing specialist in perspective on social affiliation, and regular measurement, including urban soul, arrange trust, adherence to precious models [9]. From the structures point of view, the estimations of social capital can be disengaged into three structures, including unwavering quality, data stream limit also, benchmarks joined by approvals [7] , [10]. From the attributes viewpoint, it will all in all be disconnected as aide estimation, social estimation, and asset estimation [11]. In addition, there are still some various decisions about the estimations of social capital, for instance, cross social capital and holding social capital [12], instrumental ties and expressive ties [13], mental estimation, social estimation and fundamental estimation [5] , [10].

The components of social capital likewise can influence at the individual dimension. Since entertainers are the direct participators of the casual network, so the prompt effects of both unquestionable and interactional estimations of social capital are at the individual dimension. Essential social capital has indispensable effect at the individual dimension. For example, individuals found halfway inside system are less inclined to be discouraged than those on the outskirts [14], be that as it may, the centrality may likewise cause a few negative impacts, accept the star representative for instance, since the superior and high deceivability, star workers are generally found halfway inside the system, in spite of the more data got and sent, they may likewise encounter data over-burden [15]. Another essential areas are about the holding and crossing over, particularly the spanning, crossing over ties associate assorted social

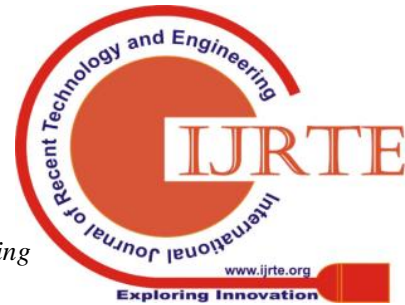




\section{DESCRIPTIVE RESEARCH OF SOCIAL CAPITAL AMONG LOW INCOME GROUP IN URBAN AREAS IN EAST COAST OF PENINSULAR MALAYSIA}

gatherings, while holding ties just associate performing artists in a similar gathering [4], as indicated by the crossing over and holding hypothesis, individuals in a similar gathering may claim comparative assets, if association with alternate gatherings, individuals can access to distinctive assets, consequently can profit the people, numerous explores have demonstrate that crossing over can decidedly influence singular level results, including work looking for prospects [16], profession achievement [17]. In others researches, coordinated at national and comprehensive levels, have demonstrated that the parts of social capital, generally social trust, effectively influence individuals' prosperity which is not real by budgetary criteria [18]. This is a demonstrated truth that social capital has a positive relationship with physical and vigorous prosperity, social affiliations, and ordinary flourishing [19]. In the open field where individuals have higher social capital, there are sliced down rates of repulsive direct and progressively lifted extents of individual fulfillment [20].

In this study, there are six components of social capital that has been tried which are systems and correspondences; trust; esteem, standards and propensities; social principles; capacity or ability; religious needs. The past investigates that directed by [21], [22] additionally utilized these measurements as a piece of factors. In light of the past examinations and researchers in this documented, every one of these measurements are significant components of social capital.

\section{METHODOLOGY}

The investigation was used a cross sectional overview by quantitative techniques. The populations were low salary family units in urban zones in east coast of peninsular Malaysia which are, Kuantan, Kuala Terengganu and Kota Bharu. This survey utilizes five-scale, beginning from the lowest to the highest which are one to five scales. The instrument contains six measurements that were to analysis factors of social capital. A sum of 288 respondents has been selected as a sample in this research addressed the survey. The data was analyzed using SPSS programming.

\section{RESULTS AND DISCUSSION}

Based on Table 1, the value of Cronbach's Alpha for dimensions of social capital is $0.784,0.807,0.842,0.841$, 0.889 and 0.898 respectively. The majority of the over Cronbach's Alpha approval exceeds 0.6 methods the above things are reasonable for utilize and acceptable as valuation [23]-[25].

Table 1: The value of Cronbach's Alpha

\begin{tabular}{|c|c|c|}
\hline & $\begin{array}{c}\text { Numbers } \\
\text { of Item }\end{array}$ & $\begin{array}{c}\text { Cronbach's } \\
\text { Alpha }\end{array}$ \\
\hline Network and Communications & 9 & 0.784 \\
\hline Trust & 10 & 0.807 \\
\hline Value, Norms and Habits & 10 & 0.842 \\
\hline Social rules & 10 & 0.841 \\
\hline Capability or Ability & 10 & 0.889 \\
\hline Religious Needs & 10 & 0.898 \\
\hline
\end{tabular}

Table 2 demonstrates the graphic measurements of social capital among low salary in urban zones in east coast of peninsular Malaysia. The measurements demonstrates these measurements, method and correspondence (mean=3.2747, sexually transmitted disease. dev. $=0.39099)$; trust (mean $=3.3458, \quad$ sexually transmitted disease. dev. $=0.36566$, ; esteem, standards and propensities (mean $=3.3580$, sexually transmitted disease. dev. $=0.37538$ ); social principles (mean $=3.3347$, sexually transmitted disease. dev. $=0.37432$ ); capacity or ability (mean=3.4125, sexually transmitted disease. dev. $=0.39321$ ) and religious needs (mean $=3.5743$, sexually transmitted disease. dev. $=0.37902$, .

\section{Table 2: The graphic measurements of social capital among low salary in urban zones in east coast of peninsular Malaysia}

\begin{tabular}{|c|c|c|c|c|}
\hline Social Capital Index & Min & Max & Mean & SD \\
\hline $\begin{array}{c}\text { Network and } \\
\text { Communications }\end{array}$ & 2.33 & 4.00 & 3.2747 & .39099 \\
\hline Trust & 2.40 & 4.00 & 3.3458 & .36566 \\
\hline $\begin{array}{c}\text { Value, Norms and } \\
\text { Habits }\end{array}$ & 2.40 & 4.00 & 3.3580 & .37538 \\
\hline Social rules & 2.30 & 4.00 & 3.3347 & .37432 \\
\hline $\begin{array}{c}\text { Capability or } \\
\text { Ability }\end{array}$ & 2.50 & 4.00 & 3.4125 & .39321 \\
\hline Religious Needs & 2.60 & 4.00 & 3.5743 & .37902 \\
\hline
\end{tabular}

Measurement of religious needs demonstrates the most astounding mean score and measurement of systems and correspondences demonstrates the least mean score [26][28]. From these outcomes, it demonstrates that element of systems and interchanges should be improved and measurement of religious needs is as of now at the abnormal states yet at the same time need to keep up so the general estimation of social capital among respondents can generally be at the abnormal states.

Each of the factors measurements of social capital show a min more noteworthy than 3 . This demonstrates the dimension of social capital is high in light of the fact that the middle scale for this scale is 3 . In the event that the esteem is more prominent than 3 , it is considered on a par with it is nearer to the esteem 5 . Then again, if the mean estimation of the score is lower than 3 , the variable's dimension is viewed as low since it is moving toward the base esteem 1 . The scale of this measurement refers to the study conducted by [29], [30]. Hence, all the variables of social capital at high levels.

\section{CONCLUSION}

In conclusion, it can characterize that the social capital of respondentswere at a decent dimension. Be that as it may, despite everything it can be improve so as to achieve more elevated amount. As said by [15] people found mostly inside framework are less inspired to be disheartened than those on the outskirts in any case the centrality may similarly cause a couple of antagonistic effects. From this talk, the social

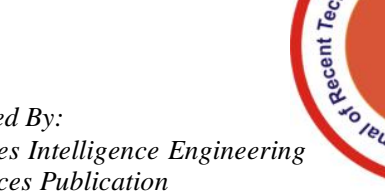

and Engin IJTRE IJRT

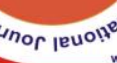
www.jitte.org 
capital can be a significant job to convey social orders particularly low-pay gathering to a superior life.

Besides the government can utilized this result as a foundation to create a policies or programs, others researchers are encourage expanding this research. In future, others analysts can improve this exploration by investigate others measurement or respondents. What's more, perhaps analysts or academicians can give materials or instruments

\section{ACKNOWLEDGMENT}

This project has been funded by the Ministry of Education Malaysia via the Fundamental Research Grant Scheme FRGS (FRGS / 1/2017 / SS06 / UniSZA / 01/1 / RR243). The authors would like to thank the Research Management, Innovation and Commercialization Centre, Universiti Sultan Zainal Abidin, Terengganu, Malaysia for providing the financial assistance to support the publication fee of this article.

\section{REFERENCES}

1. S. Dalhatu, N. A. Ghani, V. Bozkurt, "A systematic review on factors affecting community participation towards polio immunization in Nigeria," Mediterranean Journal of Social Sciences, 6(2 S1), 2015, pp. 407-415.

2. A. Amin, A. M. Salleh, M. S. Muda, and Y. Ibrahim, "A predictive determinant of quality of life among homestay program participants in Malaysia," Asian Social Science, 9(3),

3. R. Putnam, "The prosperous community: social capital and public life," in Cross Currents: Cultures, Communities, Technologies, K. Blair, R. M. Murphy, and J. Almjeld, Boston: Cengage Learning, 2013, pp. 249-274.

4. R. D. Putnam, Bowling Alone: The Collapse and Revival of American Community. New York: Simon and Shuster, 2000.

5. J. Nahapiet, and S. Ghoshal, "Social capital, intellectual capital, and the organizational advantage," Academy of Management Review, 23(2), 1998, pp. 242-266.

6. R. S. Burt, Structural holes: The social structure of competition. Massachusetts: Harvard University Press, 2009.

7. J. S. Coleman, "Social capital in the creation of human capital," American Journal of Sociology, 94, 1988, pp. S95120.

8. Z. Zolkifeli, and A. Amin, "The effects of social capital and mental health on quality of life among low income group in urban areas in east coast of Peninsula Malaysia," International Journal of Civil Engineering and Technology, 9(8), 2018, pp. 904-909.

9. M. Kilduff, and D. J. Brass, "Organizational social network research: Core ideas and key debates," Academy of Management Annals, 4(1), 2010, pp. 317-357.

10. W. P. Wu, "Dimensions of social capital and firm competitiveness improvement: The mediating role of information sharing," Journal of Management Studies, 45(1), 2008, pp. 122-146.

11. I. Castro, and J. L. Roldán, "A mediation model between dimensions of social capital," International Business Review, 22(6), 2013, pp. 1034-1050.

12. F. X. Molina-Morales, and M. T. Martínez-Fernández, "Social networks: Effects of social capital on firm innovation," Journal of Small Business Management, 48(2), 2010, pp. 258279.

13. H. Ibarra, and S. B. Andrews, "Power, social influence, and sense making: Effects of network centrality and proximity on employee perceptions," Administrative Science Quarterly, 38(2), 1993, pp. 277-303. about social capital intrigue. 2013, pp. 33-41.

14. J. N. Rosenquist, J. H. Fowler, and N. A. Christakis, "Social network determinants of depression," Molecular Psychiatry, 6(3), 2011, pp. 1-20.

15. J. B. Oldroyd, and S. S. Morris, "Catching falling stars: A human resource response to social capital's detrimental effect of information overload on star employees," Academy of Management Review, 37(3), 2012, pp. 396-418.

16. M. Granovetter, "Economic action and social structure: The problem of embeddedness," American Journal of Sociology, 91(3), 1985, pp. 481-510.

17. J. M. Podolny, and J. N. Baron, "Resources and relationships: Social networks and mobility in the workplace," American Sociological Review, 62(5), 1997, pp. 673-93.

18. J. F. Helliwell, "Well-being, social capital and public policy: What's new?" Economic Journal, 116(510), 2006, pp. C34-45.

19. R. M. Scheffler, T. T. Brown, L. Syme, I. Kawachi, I. Tolstykh, and C. Iribarren, "Community-level social capital and recurrence of acute coronary syndrome," Social Science and Medicine, 66(7), 2008, pp. 1603-1613.

20. J. R. Masalu, and A. N. Åstrøm, "Social and behavioral correlates of oral quality of life studied among university students in Tanzania," Acta Odontologica Scandinavica, 60(6), 2002, pp. 353-359.

21. A. Amin, A. P. M. Som, and Z. Zolkifeli, "Social capital impact on quality of life of low-income population group," International Journal of Engineering \& Technology, 7(4.34), 2018, pp. 137-139.

22. A. Amin, and Z. Zolkifeli, "Analysis dimensions of social capital among poverty group in suburbs areas," Journal of Social Sciences Research, 4(12), 2018, pp. 618-620.

23. W. M. Cates, Panduan Amali untuk Penyelidikan Pendidikan (Terjemahan). Kuala Lumpur: Dewan Bahasa dan Pustaka, 1990.

24. A. Azid, H. Juahir, E. Ezani, M. E. Toriman, A. Endut, M. N. A. Rahman, K. Yunus, M. K. A. Kamarudin, C. N. C. Hasnam, A.S.M. Saudi, and R. Umar, "Identification source of variation on regional impact of air quality pattern using chemometric," Aerosol and Air Quality Research, 15(4), 2015, pp. 1545-1558.

25. A. Endut, S. H. Y. S. Abdullah, N. H. M. Hanapi, S. H. A. Hamid, F. Lananan, M. K. A. Kamarudin, R. Umar, H. Juahir, and H. Khatoon, "Optimization of biodiesel production by solid acid catalyst derived from coconut shell via response surface methodology," International Biodeterioration and Biodegradation, 124, 2017, pp. 250-257.

26. A. Amin, and Y. Ibrahim, "Model of sustainable community participation in homestay program," Mediterranean Journal of Social Sciences, 6(3), 2015, pp. 539-545.

27. N. A. Amirah, W. I. Asma, M. S. Muda, W. A. A. W. M. Amin, "Safety culture in combating occupational safety and health problems in the Malaysian manufacturing sectors," Asian Social Science, 9(3), 2013, pp. 182-191.

28. A. Amin, and Y. Ibrahim, "Sustainable community participation in homestay program, International Business Management, 10(1), 2016, pp. 18-23.

29. M. S. Muda, W. A. Amin, and N. W. Omar, "Analisis kesejahteraan hidup nelayan pesisir," Jurnal Kemanusiaan, 4(2), 2006, pp. 58-77.

30. Malaysia Department of Statistics, Statistik pendapatan dan perbelanjaan isi rumah. 2016, Available: https://www.dosm.gov.my/v1/index.php?r=column/ctwoByCa t\&parent_id=119\&menu_id=amVoWU54UT10a 21NWmdhMjFMMWcyZzz09. 